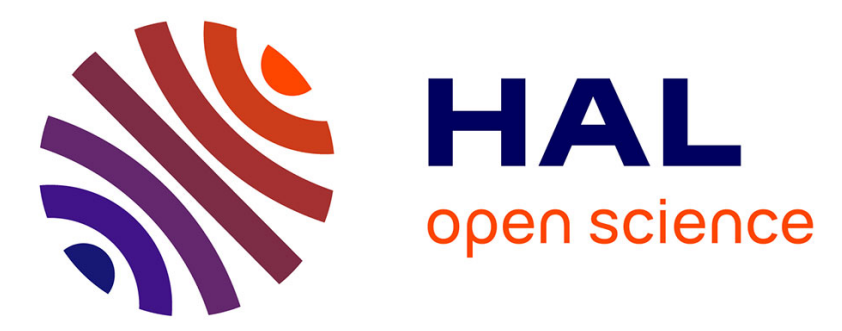

\title{
Crop management systems for rainfed and irrigated sunflower (Helianthus annuus) in South-Western France
}

Philippe P. Debaeke, M Cabelguenne, A. Hilaire, Didier Raffaillac

\section{To cite this version:}

Philippe P. Debaeke, M Cabelguenne, A. Hilaire, Didier Raffaillac. Crop management systems for rainfed and irrigated sunflower (Helianthus annuus) in South-Western France. Journal of Agricultural Science, 1998, 131 (Part.2), pp.171-185. 10.1017/S0021859698005747 . hal-02695962

\section{HAL Id: hal-02695962 \\ https://hal.inrae.fr/hal-02695962}

Submitted on 1 Jun 2020

HAL is a multi-disciplinary open access archive for the deposit and dissemination of scientific research documents, whether they are published or not. The documents may come from teaching and research institutions in France or abroad, or from public or private research centers.
L'archive ouverte pluridisciplinaire HAL, est destinée au dépôt et à la diffusion de documents scientifiques de niveau recherche, publiés ou non, émanant des établissements d'enseignement et de recherche français ou étrangers, des laboratoires publics ou privés. 


\title{
Crop management systems for rainfed and irrigated sunflower (Helianthus annuus) in south-western France
}

\author{
P. DEBAEKE*, M. CABELGUENNE, A. Hilaire and D. RAFFAILlAC \\ INRA, Station d'Agronomie, BP 27, 31326 Castanet-Tolosan cedex, France \\ (Revised MS received 6 March 1998)
}

\begin{abstract}
SUMMARY
In the context of EEC agricultural policy, the efficient production of sunflower (Helianthus annuus L.) requires the development of a wider range of crop management schemes than were used previously. Five different management options were applied to sunflower over a period of 10 years (1984-94) on a deep silty clay soil at Auzeville, near Toulouse, south-western France, combining different levels of crop density, $\mathrm{N}$ fertilization and supplementary irrigation. The effectiveness of these practices was evaluated on the basis of grain yield, oil production, amount of disease infection, $\mathrm{N}$ leaching, soil water deficit and economic return, using both experimental values and simulations with the EPICPhase model.

Grain yield ranged from $1 \mathrm{t} / \mathrm{ha}$ (with severe disease incidence) to $4 \mathrm{t} / \mathrm{ha}$ (no diseases, full irrigation). There was no evidence of higher yield variability between years for low-input cropping systems managed without irrigation.

In the deep soils of Auzeville, $c .100 \mathrm{~mm}$ of irrigation, split into two or three applications around flowering, appeared to be a good strategy for maximizing irrigation efficiency. Limiting leaf area expansion under rainfed management, by reducing crop density and $\mathrm{N}$ fertilization, limited stem infection frequency by Phomopsis helianthi and delayed soil water depletion, thus maximizing grain yield. Oil concentration was generally higher under full irrigation, but high values were also observed under rainfed conditions provided that a suitable genotype was used. The annual amount of $\mathrm{N}$ leaching, simulated by EPIC-Phase, ranged from 17 to $40 \mathrm{~kg} / \mathrm{ha}$ depending on $\mathrm{N}$ amount and irrigation volume. Under the current conditions of the Common Agricultural Policy, low-input and rainfed management appeared to be the most profitable strategy for the deep soils of south-western France.
\end{abstract}

\section{INTRODUCTION}

During the 1980s, when crop prices were high, the area under sunflower (Helianthus annuus L.) in France increased rapidly (as in Spain and Italy), as did grain yields, as a consequence of irrigation use, genetic improvement (the use of cv. Mirasol) and cropping on deep soils (Cabelguenne \& Marty 1983). Since the late 1980s, sunflower areas have been more or less stable, fluctuating around 900000 ha. Yields have also tended to stabilize (SCEES 1996a), as a result of severe drought (1989-91), diseases such as brown stem canker (Phomopsis helianthi Munt.-Cvet.) (1992-93), a general reduction of inputs, and cropping on shallower soils. A wider range of crop management strategies was introduced, as a response to the significant drop in prices after CAP reform in 1992

* To whom all correspondence should be addressed. Email:debaeke@toulouse.inra.fr
(SCEES 1996b); managing sunflower under lowinput systems to reduce the production costs is now more frequent than formerly (Poiret 1996). Sunflower disappeared from irrigated cropping systems and the frequency of sunflower in crop rotations increased on less productive soils.

The adaptation of sunflower to a wider range of production goals such as maximizing grain yield, oil concentration, or gross margin, reducing working time and limiting environmental side effects, requires the development of a diversity of consistent crop management schemes. The effects of soil tillage (Deibert 1989), sowing date (Gimeno et al. 1989; Dixon \& Lutman 1992), sowing density or row spacing (Alessi et al. 1977), amount of nitrogen (Blanchet et al. 1987; Vannozzi et al. 1990) and volume of irrigation (Quaglietta Chiarandà \& d'Andria 1994) on grain yield and oil content were often studied in classical experiments, combining one or two production factors. However, only a limited 
Table 1. Elements of sunflower management differing from year to year (1984-94). LR $=$ low-input rainfed management, $M R=$ medium-input rainfed management, $H R=$ high-input rainfed management, $M I=m e d i u m-$ input irrigated management, $H I=$ high-input irrigated management

\begin{tabular}{|c|c|c|c|c|c|c|}
\hline Year & $\begin{array}{l}\text { Management... } \\
\text { Crop rotation*... }\end{array}$ & $\begin{array}{l}\text { LR } \\
\text { A \& B }\end{array}$ & $\begin{array}{l}\mathrm{MR} \\
\mathrm{A} \& \mathrm{~B}\end{array}$ & $\begin{array}{l}\mathrm{HR} \\
\mathrm{A}\end{array}$ & $\begin{array}{l}\text { MI } \\
\text { B }\end{array}$ & $\begin{array}{l}\mathrm{HI} \\
\mathrm{B}\end{array}$ \\
\hline 1984 & $\begin{array}{l}\text { Cultivar } \\
\text { Sowing date } \\
\text { Sowing density (/ha) } \\
\text { Fungicide } \\
\text { Irrigation (mm) }\end{array}$ & $\begin{array}{l}\text { Topflor } \\
\text { March } 26 \\
71000 \\
\text { None } \\
0\end{array}$ & $\begin{array}{l}\text { Topflor } \\
\text { March } 26 \\
71000 \\
\text { None } \\
0\end{array}$ & $\begin{array}{l}\text { Topflor } \\
\text { March } 26 \\
71000 \\
\text { None } \\
0\end{array}$ & $\begin{array}{l}\text { Topflor } \\
\text { March } 26 \\
71000 \\
\text { None } \\
155(5)\end{array}$ & $\begin{array}{l}\text { Topflor } \\
\text { March } 26 \\
71000 \\
\text { None } \\
215(6)\end{array}$ \\
\hline 1985 & $\begin{array}{l}\text { Cultivar } \\
\text { Sowing date } \\
\text { Sowing density }(/ \mathrm{ha}) \\
\text { Fungicide } \\
\text { Irrigation }(\mathrm{mm})\end{array}$ & $\begin{array}{l}\text { Topflor } \\
\text { April 1 } \\
77000 \\
\text { None } \\
0\end{array}$ & $\begin{array}{l}\text { Topflor } \\
\text { April 1 } \\
77000 \\
\text { None } \\
0\end{array}$ & $\begin{array}{l}\text { Topflor } \\
\text { April 1 } \\
77000 \\
\text { None } \\
0\end{array}$ & $\begin{array}{l}\text { Topflor } \\
\text { April 1 } \\
77000 \\
\text { None } \\
80(3)\end{array}$ & $\begin{array}{l}\text { Topflor } \\
\text { April 1 } \\
77000 \\
\text { None } \\
215(9)\end{array}$ \\
\hline 1986 & $\begin{array}{l}\text { Cultivar } \\
\text { Sowing date } \\
\text { Sowing density }(/ \mathrm{ha}) \\
\text { Fungicide (a.i., } \mathrm{kg} / \mathrm{ha}) \\
\text { Irrigation }(\mathrm{mm})\end{array}$ & $\begin{array}{l}\text { Topflor } \\
\text { March } 28 \\
77300 \\
\text { None } \\
0\end{array}$ & $\begin{array}{l}\text { Topflor } \\
\text { March } 28 \\
77300 \\
\text { Benomyl } 0 \cdot 2 \\
0\end{array}$ & $\begin{array}{l}\text { Topflor } \\
\text { March } 28 \\
77300 \\
\text { Benomyl } 0 \cdot 2 \\
0\end{array}$ & $\begin{array}{l}\text { Topflor } \\
\text { March } 28 \\
77300 \\
\text { Benomyl } 0 \cdot 2 \\
110(3)\end{array}$ & $\begin{array}{l}\text { Topflor } \\
\text { March } 28 \\
77300 \\
\text { Benomyl } 0 \cdot 2 \\
210(6)\end{array}$ \\
\hline 1987 & $\begin{array}{l}\text { Cultivar } \\
\text { Sowing date } \\
\text { Sowing density (/ha) } \\
\text { Fungicide (a.i., kg/ha) } \\
\text { Irrigation (mm) }\end{array}$ & $\begin{array}{l}\text { Viki } \\
\text { April } 16 \\
66600 \\
\text { None } \\
0\end{array}$ & $\begin{array}{l}\text { Viki } \\
\text { April } 16 \\
66600 \\
\text { None } \\
0\end{array}$ & $\begin{array}{l}\text { Viki } \\
\text { April } 16 \\
66600 \\
\text { Maneb } 1 \cdot 8 \\
0\end{array}$ & $\begin{array}{l}\text { Viki } \\
\text { April } 16 \\
89300 \\
\text { None } \\
90(2)\end{array}$ & $\begin{array}{l}\text { Viki } \\
\text { April } 16 \\
89300 \\
\text { Maneb } 1 \cdot 8 \\
130(3)\end{array}$ \\
\hline 1988 & $\begin{array}{l}\text { Cultivar } \\
\text { Sowing date } \\
\text { Sowing density (/ha) } \\
\text { Fungicide (a.i., kg/ha) } \\
\text { Irrigation (mm) }\end{array}$ & $\begin{array}{l}\text { Viki } \\
\text { April } 13 \\
66600 \\
\text { None } \\
0\end{array}$ & $\begin{array}{l}\text { Viki } \\
\text { April } 13 \\
66600 \\
\text { Maneb 2·1 } \\
0\end{array}$ & $\begin{array}{l}\text { Viki } \\
\text { April } 13 \\
66600 \\
\text { Maneb 2·1 } \\
0\end{array}$ & $\begin{array}{l}\text { Viki } \\
\text { April } 13 \\
89300 \\
\text { Maneb 2·1 } \\
80(3)\end{array}$ & $\begin{array}{l}\text { Viki } \\
\text { April } 13 \\
89300 \\
\text { Maneb 2·1 } \\
120(4)\end{array}$ \\
\hline 1989 & $\begin{array}{l}\text { Cultivar } \\
\text { Sowing date } \\
\text { Sowing density (/ha) } \\
\text { Fungicide (a.i., kg/ha) } \\
\text { Irrigation (mm) }\end{array}$ & $\begin{array}{l}\text { TN } 15 \\
\text { April } 6 \\
70000 \\
\text { None }\end{array}$ & $\begin{array}{l}\text { TN } 15 \\
\text { April } 6 \\
70000 \\
\text { None }\end{array}$ & $\begin{array}{l}\text { Viki } \\
\text { April } 6 \\
90000 \\
\text { None }\end{array}$ & $\begin{array}{l}\text { TN } 15 \\
\text { April } 6 \\
70000 \\
\text { None } \\
120(3)\end{array}$ & $\begin{array}{l}\text { Viki } \\
\text { April } 6 \\
104000 \\
\text { Fluzilazol } 0 \cdot 2+ \\
\text { carbendazim } 0 \cdot 1 \\
200(5)\end{array}$ \\
\hline 1990 & $\begin{array}{l}\text { Cultivar } \\
\text { Sowing date } \\
\text { Sowing density (/ha) } \\
\text { Fungicide (a.i., kg/ha) } \\
\text { Irrigation (mm) }\end{array}$ & $\begin{array}{l}\text { Agrisol (B) } \\
\text { /Viki (A) } \\
\text { April 11 } \\
67000 \\
\text { None } \\
0\end{array}$ & $\begin{array}{l}\text { Agrisol (B) } \\
\text { /Viki (A) } \\
\text { April 11 } \\
67000 \\
\text { None } \\
0\end{array}$ & $\begin{array}{l}\text { Viki } \\
\text { April } 11 \\
67000 \\
\text { Fluzilazol } 0 \cdot 2+ \\
\text { carbendazim } 0 \cdot 1 \\
0\end{array}$ & $\begin{array}{l}\text { Agrisol } \\
\text { April } 11 \\
77000 \\
\text { None } \\
90(3)\end{array}$ & $\begin{array}{l}\text { Viki } \\
\text { April } 11 \\
77000 \\
\text { Fluzilazol } 0 \cdot 2+ \\
\text { carbendazim } 0 \cdot 1 \\
150(5)\end{array}$ \\
\hline 1991 & $\begin{array}{l}\text { Cultivar } \\
\text { Sowing date } \\
\text { Sowing density }(/ \mathrm{ha}) \\
\text { Fungicide (a.i., kg/ha) } \\
\text { Irrigation }(\mathrm{mm})\end{array}$ & $\begin{array}{l}\text { Agrisol } \\
\text { April } 10 \\
65000 \\
\text { None } \\
0\end{array}$ & $\begin{array}{l}\text { Agrisol } \\
\text { April } 10 \\
65000 \\
\text { None }\end{array}$ & $\begin{array}{l}\text { Viki } \\
\text { April } 10 \\
65000 \\
\text { Fluzilazol } 0 \cdot 2+ \\
\text { carbendazim } 0 \cdot 1 \\
0\end{array}$ & $\begin{array}{l}\text { Agrisol } \\
\text { April } 10 \\
75000 \\
\text { None } \\
80(2)\end{array}$ & $\begin{array}{l}\text { Viki } \\
\text { April } 10 \\
77000 \\
2 \times \text { Fluzilazol } 0 \cdot 2+ \\
\text { carbendazim } 0 \cdot 1 \\
110(2)\end{array}$ \\
\hline 1992 & $\begin{array}{l}\text { Cultivar } \\
\text { Sowing date } \\
\text { Sowing density }(/ \mathrm{ha}) \\
\text { Fungicide } \\
\text { Irrigation }(\mathrm{mm})\end{array}$ & $\begin{array}{l}\text { Select } \\
\text { April } 21 \\
50000 \\
\text { None } \\
0\end{array}$ & $\begin{array}{l}\text { Select } \\
\text { April } 21 \\
65000 \\
\text { None } \\
0\end{array}$ & $\begin{array}{l}\text { Viki } \\
\text { April } 21 \\
65000 \\
\text { None } \\
0\end{array}$ & $\begin{array}{l}\text { Select } \\
\text { April } 21 \\
65000 \\
\text { None } \\
0\end{array}$ & $\begin{array}{l}\text { Viki } \\
\text { April } 21 \\
65000 \\
\text { None } \\
0\end{array}$ \\
\hline 1994 & $\begin{array}{l}\text { Cultivar } \\
\text { Sowing date } \\
\text { Sowing density (/ha) } \\
\text { Fungicide (a.i., } \mathrm{kg} / \mathrm{ha}) \\
\text { Irrigation (mm) }\end{array}$ & $\begin{array}{l}\text { Select } \\
\text { May } 3 \\
61300 \\
\text { None } \\
0\end{array}$ & $\begin{array}{l}\text { Select } \\
\text { May } 3 \\
77300 \\
\text { None }\end{array}$ & $\begin{array}{l}\text { Select } \\
\text { May } 3 \\
77300 \\
\text { Fluzilazol } 0 \cdot 2+ \\
\text { carbendazim } 0 \cdot 1 \\
0\end{array}$ & $\begin{array}{l}\text { Select } \\
\text { May } 3 \\
77300 \\
\text { None } \\
45(1)\end{array}$ & $\begin{array}{l}\text { Select } \\
\text { May } 3 \\
77300 \\
\text { Fluzilazol } 0 \cdot 2+ \\
\text { carbendazim } 0 \cdot 1 \\
95(2)\end{array}$ \\
\hline
\end{tabular}

* See text for details. 
number of factorial combinations can be studied in such experiments. Another way is to devise and compare, at field level, several logical and consistent sequences of cultivation techniques, according to the objectives and constraints of crop production (Meynard 1985; Capillon \& Fleury 1986; Debaeke \& Hilaire 1991). This systems approach has been applied to sunflower in a limited number of situations only (Reau \& Wagner 1994; Bonari et al. 1996).

The objective of this study was to evaluate a range of management options for sunflower production applied during ten successive years on a deep alluvial soil in south-western France. Since the Common Agricultural Policy (CAP) reform in 1992, a new system of crop prices, fixed subsidies, and compulsory set-aside has been introduced. The consequences of this new policy on sunflower gross margins under different input levels was evaluated using the 10-year experimental variability and the related operating costs.

\section{MATERIALS AND METHODS}

A long-term field trial (1984-94) was conducted at Auzeville (latitude $43^{\circ} 55^{\prime}$ ) at the Agronomic Research Station of the National Institute of Agronomic Research (INRA) located near Toulouse, in southwestern France. The soil was a deep silty clay loam. Available soil water was $c .150 \mathrm{~mm}$ per $\mathrm{m}$ depth. In autumn 1983, soil tests indicated a $\mathrm{pH}$ of $6 \cdot 8,18$ $\mathrm{mg} / \mathrm{kg}$ of extractable orthophosphate-P (Olsen et al. 1954), $148 \mathrm{mg} / \mathrm{kg}$ of exchangeable $\mathrm{K}$ (Metson 1956) and $1.6 \%$ organic matter in the $0-30 \mathrm{~cm}$ soil layer. The plot size of $18 \times 30 \mathrm{~m}$ permitted the use of ordinary farming machinery.

\section{Experiment 1: design (1984-92)}

Experiment 1 is a part of a long-term comparison of different technical sequences applied to nine crops included in ten crop rotations managed under rainfed conditions or with supplementary irrigation (Debaeke \& Hilaire 1997). The experiment was initiated in autumn 1983 on land previously sown with wheat $(1981 / 82)$ and ryegrass $(1982 / 83)$. The same degree of intensification was applied to the complete crop rotation from 1984 onwards.

Sunflower was grown in two 4-year rotations, using the normal regional practices: $(\mathrm{A})$ sunflower-winter wheat-oilseed rape-winter wheat, and (B) sunflowerwinter wheat-grain sorghum-winter wheat (or winter barley). In rotation A, sunflower was not irrigated but three different degrees of intensification were applied (low, LR; medium, MR; high, HR). In rotation B, four different input levels were applied either with (medium, MI; high, HI) and without irrigation (low,
LR; medium, MR). From the rainfed low-input treatment (LR) to the fully irrigated high-input treatment (HI), the NPK fertilizer amounts, the number of pesticide applications, and the plant population steadily increased. Crop management was not affected by the type of crop rotation. The effect of increasing inputs under rainfed conditions was analysed in rotation $\mathrm{A}$; rotation $\mathrm{B}$ was used to study the response of sunflower to supplementary irrigation. The spatial arrangement of rotations, rotation phases and sequences of technical operations within each phase was initially randomized. However, there was no replication of the latter factor in space because of the size of the whole experiment. On the 72 plots of the experiment, only seven were planted with sunflower each year from 1984 to 1992. As technical sequences were compared in adjacent plots to reduce the effects of soil variability, and as soil depth is not a limiting factor at Auzeville, we assumed very limited effects on sunflower grain yield of possible differences in soil physical environment between treatments. In a preceding experiment (1973-80), which was arranged as a four-block design, Rellier (1981) did not find any significant influence of soil type (block factor) on wheat grain yield, which indicates rather homogeneous soil conditions.

\section{Experiment 2: design (1994)}

At the end of the previous experiment, a single wheat crop was grown in 1992/93 to reveal the cumulative effects of the 9-year experiment (Debaeke et al. 1996). A single sunflower crop (cv. Select) was then sown on 3 May 1994 on each of the 72 plots. The crop management programmes were similar to the previous ones (Table 1). As each phase of the crop rotation was present each year, four blocks were available in 1994 for statistical comparisons. On each plot, a lateral band $\left(90 \mathrm{~m}^{2}\right)$ was kept free of $\mathrm{N}$ fertilizer in 1994. Technical sequence was considered as a sub-block for $\mathrm{N}$ response comparison.

\section{Crop management}

Cultivars changed between years and between degrees of intensification (Table 1). Genetic improvement was taken into consideration. For instance, cultivars less productive but more tolerant to Phomopsis helianthi (e.g. cvs TN15 and Agrisol) were preferred under low-input management from 1989 onwards. The cultivars did not differ much in their earliness: $c .1650$ growing degree-days were required from emergence to physiological maturity (temperature threshold of $6{ }^{\circ} \mathrm{C}$ ) (Table 2). The genotypic variations in oil concentration or 1000 -seed weight were taken into consideration when analysing the results.

In both experiments, sunflower was sown after 
Table 2. Main characteristics of the sunflower cultivars used in Expts 1 and 2

\begin{tabular}{|c|c|c|c|c|}
\hline Cultivar & Earliness & $\begin{array}{l}\text { Tolerance } \\
\text { to Phomopsis } \\
\text { helianthi* }^{*}\end{array}$ & Oil content & $\begin{array}{l}\text { Reference } \\
1000 \text {-seed } \\
\text { weight }(\mathrm{g})\end{array}$ \\
\hline Agrisol & $\begin{array}{l}\text { Mid-early } \\
\text { to mid-late }\end{array}$ & TPSA & Medium & 62 \\
\hline Frankasol & $\begin{array}{l}\text { Early to } \\
\text { mid-early }\end{array}$ & S & Medium & 60 \\
\hline Select & $\begin{array}{l}\text { Mid-early } \\
\text { to mid-late }\end{array}$ & TPS & Very high & 50 \\
\hline TN15 & $\begin{array}{l}\text { Early to } \\
\text { mid-early }\end{array}$ & TPS & Medium & 45 \\
\hline Topflor & Mid-late to late & $\mathrm{S}$ & Very high & 48 \\
\hline Viki & $\begin{array}{l}\text { Mid-early } \\
\text { to mid-late }\end{array}$ & $\mathrm{S}$ & High & 48 \\
\hline
\end{tabular}

* Tolerance to Phomopsis helianthi: TPSA $>$ TPS $>$ PS $>$ S.

Table 3. Monthly weather data (1984-94) at the INRA Research Station, Auzeville, near Toulouse, south-western France

\begin{tabular}{|c|c|c|c|c|c|c|c|c|}
\hline & March & April & May & June & July & August & September & Mar-Sep \\
\hline \multicolumn{9}{|l|}{1984} \\
\hline Temperature $\left({ }^{\circ} \mathrm{C}\right)$ & $7 \cdot 2$ & $11 \cdot 8$ & $12 \cdot 4$ & $17 \cdot 8$ & $21 \cdot 2$ & $19 \cdot 6$ & $16 \cdot 4$ & $15 \cdot 2$ \\
\hline Precipitation (mm) & 32 & 46 & 105 & 62 & 16 & 71 & 99 & 431 \\
\hline \multicolumn{9}{|l|}{1985} \\
\hline Temperature $\left({ }^{\circ} \mathrm{C}\right)$ & $7 \cdot 3$ & $12 \cdot 2$ & $13 \cdot 7$ & $17 \cdot 8$ & $21 \cdot 9$ & $19 \cdot 5$ & $19 \cdot 8$ & $16 \cdot 0$ \\
\hline Precipitation (mm) & 66 & 65 & 109 & 65 & 38 & 11 & 0 & 354 \\
\hline \multicolumn{9}{|l|}{1986} \\
\hline Temperature $\left({ }^{\circ} \mathrm{C}\right)$ & $8 \cdot 8$ & $8 \cdot 5$ & $15 \cdot 5$ & $17 \cdot 8$ & $20 \cdot 2$ & $20 \cdot 5$ & $18 \cdot 7$ & $15 \cdot 7$ \\
\hline Precipitation (mm) & 47 & 72 & 47 & 14 & 7 & 21 & 41 & 249 \\
\hline \multicolumn{9}{|l|}{1987} \\
\hline Temperature $\left({ }^{\circ} \mathrm{C}\right)$ & $7 \cdot 5$ & $12 \cdot 9$ & $13 \cdot 1$ & $16 \cdot 9$ & $20 \cdot 7$ & $21 \cdot 1$ & $20 \cdot 1$ & $16 \cdot 0$ \\
\hline Precipitation (mm) & 79 & 68 & 53 & 57 & 92 & 24 & 11 & 487 \\
\hline \multicolumn{9}{|l|}{1988} \\
\hline Temperature $\left({ }^{\circ} \mathrm{C}\right)$ & $8 \cdot 8$ & $11 \cdot 9$ & $15 \cdot 4$ & $18 \cdot 4$ & $19 \cdot 9$ & $20 \cdot 8$ & $17 \cdot 5$ & $16 \cdot 1$ \\
\hline Precipitation (mm) & 104 & 147 & 63 & 50 & 48 & 26 & 49 & 487 \\
\hline \multicolumn{9}{|l|}{1989} \\
\hline Temperature $\left({ }^{\circ} \mathrm{C}\right)$ & $11 \cdot 0$ & $10 \cdot 3$ & $17 \cdot 7$ & $19 \cdot 8$ & $22 \cdot 5$ & $22 \cdot 3$ & $17 \cdot 7$ & $17 \cdot 3$ \\
\hline Precipitation (mm) & 42 & 112 & 22 & 9 & 6 & 28 & 45 & 264 \\
\hline \multicolumn{9}{|l|}{1990} \\
\hline Temperature $\left({ }^{\circ} \mathrm{C}\right)$ & $10 \cdot 3$ & $10 \cdot 7$ & $17 \cdot 6$ & $18 \cdot 8$ & $22 \cdot 5$ & $22 \cdot 7$ & $18 \cdot 9$ & $17 \cdot 4$ \\
\hline Precipitation (mm) & 5 & 66 & 86 & 38 & 21 & 71 & 28 & 315 \\
\hline \multicolumn{9}{|l|}{1991} \\
\hline Temperature $\left({ }^{\circ} \mathrm{C}\right)$ & $11 \cdot 0$ & $10 \cdot 2$ & $13 \cdot 1$ & $17 \cdot 5$ & $21 \cdot 9$ & $23 \cdot 7$ & $20 \cdot 7$ & $16 \cdot 9$ \\
\hline Precipitation (mm) & 89 & 63 & 109 & 57 & 6 & 81 & 81 & 486 \\
\hline \multicolumn{9}{|l|}{1992} \\
\hline Temperature $\left({ }^{\circ} \mathrm{C}\right)$ & $9 \cdot 4$ & $11 \cdot 6$ & $17 \cdot 0$ & $16 \cdot 9$ & $21 \cdot 1$ & $22 \cdot 6$ & $17 \cdot 7$ & $16 \cdot 6$ \\
\hline Precipitation (mm) & 42 & 71 & 89 & 293 & 128 & 165 & 104 & 892 \\
\hline \multicolumn{9}{|l|}{1994} \\
\hline Temperature $\left({ }^{\circ} \mathrm{C}\right)$ & $6 \cdot 5$ & $10 \cdot 4$ & $16 \cdot 5$ & $19 \cdot 7$ & $23 \cdot 9$ & $23 \cdot 4$ & $17 \cdot 7$ & $16 \cdot 9$ \\
\hline Precipitation (mm) & 23 & 123 & 70 & 75 & 11 & 3 & 108 & 413 \\
\hline
\end{tabular}

winter cereals in $0.5 \mathrm{~m}$ rows oriented east-west, on land which was first ploughed and then shallow harrowed. The same sowing date was used for all management options. As spring rainfall is extremely variable in south-western France (Table 3), the actual sowing dates ranged from the end of March to early 
Table 4. Elements of sunflower management which did not change with time for a given input treatment (1984-94); $L R=$ low-input rainfed management, $M R=$ medium-input rainfed management, $H R=$ high-input rainfed management, $M I=$ medium-input irrigated management, $H I=$ high-input irrigated management

\begin{tabular}{|c|c|c|c|c|c|}
\hline \multirow{2}{*}{$\begin{array}{l}\text { Year } \\
\text { Techniques }\end{array}$} & \multicolumn{5}{|c|}{ Crop management } \\
\hline & LR & MR & HR & MI & HI \\
\hline \multicolumn{6}{|l|}{ 1984-92 } \\
\hline $\begin{array}{l}\text { Weed control } \\
\text { (a.i., } \mathrm{kg} / \mathrm{ha})\end{array}$ & $\begin{array}{l}\text { Trifluralin } 1 \cdot 2+ \\
\text { Linuron } 0 \cdot 45\end{array}$ & $\begin{array}{l}\text { Trifluralin } 1 \cdot 2+ \\
\text { Flurochloridone } 0 \cdot 5\end{array}$ & $\begin{array}{l}\text { Metolachlor } 1.9+ \\
\text { Flurochloridone } 0.5\end{array}$ & $\begin{array}{l}\text { Trifluralin } 1 \cdot 2+ \\
\text { Flurochloridone } 0.5\end{array}$ & $\begin{array}{l}\text { Metolachlor } 2 \cdot 0+ \\
\text { Flurochloridone } 0 \cdot 5\end{array}$ \\
\hline $\begin{array}{l}\mathrm{N} \text { fertilizer } \\
(\mathrm{kg} / \mathrm{ha})\end{array}$ & 50 & 80 & 120 & 130 & 170 \\
\hline $\begin{array}{l}\text { PK fertilizer } \\
(\mathrm{kg} / \mathrm{ha})\end{array}$ & $30+30$ & $150+150$ & $180+180$ & $150+150$ & $180+180$ \\
\hline \multicolumn{6}{|l|}{1994} \\
\hline $\begin{array}{c}\text { Weed control } \\
\text { (a.i., } \mathrm{kg} / \mathrm{ha})\end{array}$ & $\begin{array}{l}\text { Trifluralin } 1 \cdot 2+ \\
1 \text { hoeing }\end{array}$ & $\begin{array}{l}\text { Trifluralin } 1 \cdot 2+ \\
\text { Linuron } 0 \cdot 35\end{array}$ & $\begin{array}{l}\text { Trifluralin } 1 \cdot 2+ \\
\text { Flurochloridone } 0 \cdot 5\end{array}$ & $\begin{array}{l}\text { Trifluralin } 1 \cdot 2+ \\
\text { Linuron } 0 \cdot 35\end{array}$ & $\begin{array}{l}\text { Trifluralin } 1.2+ \\
\text { Flurochloridone } 0.5\end{array}$ \\
\hline $\begin{array}{l}\mathrm{N} \text { fertilizer } \\
(\mathrm{kg} / \mathrm{ha})\end{array}$ & 30 & 60 & 80 & 60 & 80 \\
\hline $\begin{array}{l}\text { PK fertilizer } \\
(\mathrm{kg} / \mathrm{ha})\end{array}$ & $0+0$ & $50+50$ & $100+100$ & $50+50$ & $100+100$ \\
\hline
\end{tabular}

May. When seedling population was too low $(<25000$ plants/ha) and uneven, the crop was re-sown. In 1984, 1986, 1987 and 1989, the plots were sown again after shallow cultivation (on 18 April, 6 May, 4 May and 24 April, respectively), because of low temperatures (1986), pigeon attacks $(1984,1987)$ or lack of seedbed moisture (1989). As the new sowing date was relatively late in 1986 and 1987 , an early maturing genotype (cv. Frankasol) was used for the re-sowing.

The crop density was modified during the course of the experiment (Table 1). The same density (c. 7 plants $/ \mathrm{m}^{2}$ ) was used for all treatments from 1984 to 1986. From 1987, plant density increased in irrigated plots, and from 1992, decreased for low-input management, in order to limit disease development.

$\mathrm{N}$ fertilizer amount increased from LR to HI: 50 to $170 \mathrm{~kg} /$ ha (Table 4), and was not adjusted each year for the soil $\mathrm{N}$ budget. $\mathrm{P}$ and $\mathrm{K}$ fertilization increased in the same way, from 40 to $210 \mathrm{~kg} / \mathrm{ha} \mathrm{P}_{2} \mathrm{O}_{5}$ and $\mathrm{K}_{2} \mathrm{O}$. Sprinkler irrigation was managed by regularly monitoring the soil water down to $1.6 \mathrm{~m}$ with a neutron probe throughout the growing season. Two strategies of supplementary irrigation were tested: in MI, a limited amount of water was available (c. 90-120 $\mathrm{mm}$ ) and two or three split applications were made around anthesis; while in HI, water was not limited and irrigation began earlier and stopped later. Decision rules based on soil water deficit and crop stage were applied to trigger irrigation (Debaeke \& Hilaire 1997), which led to different application volumes and schedules between one year and another. According to the limited irrigation programme (MI), three waterings were possible between the ' $3-\mathrm{cm}$ flower bud' stage and the end of anthesis ('petal-fall' stage), if less than $40 \%$ of available soil water was present at $0.4 \mathrm{~m}$ depth. According to the full irrigation programme $(\mathrm{HI})$, these applications were possible earlier (' $2-\mathrm{cm}$ flower bud' stage), if less than $60 \%$ of available soil water was present at $0.4 \mathrm{~m}$ depth; irrigation then was applied to recharge the soil water profile before anthesis and at petal-fall. Soil water content and water use were assessed only in the MR, $\mathrm{MI}$ and HI managements of rotation B.

Fungicide protection was introduced in 1986 because of the spread of Phomopsis helianthi during 1985 in south-western France (Delos \& Moinard 1995). It was used on susceptible genotypes and under high nitrogen and/or high irrigation supply treatments (Table 1). Weed control was different for each treatment; the efficacy and cost of herbicides increased from low-input to high-input management (Table 4). The occurrence and population densities of weeds, insects and diseases were routinely surveyed to help maximize the agronomic and economic efficiency of pesticide applications.

\section{Observations}

On each plot, commercial grain yield was determined at maturity by harvesting one (1994) and four (1984-92) central areas of $75 \mathrm{~m}^{2}$. Biological grain yield and yield components (number of heads $/ \mathrm{m}^{2}$, number of achenes $/ \mathrm{m}^{2}$, 1000-seed weight) were recorded from manual samplings from one $5 \mathrm{~m}^{2}$ central area per plot. Dry matter and plant $\mathrm{N}$ content 
were measured separately for grain, head and stem using the Kjeldahl method. Oil content was measured by the Nuclear Magnetic Resonance (NMR) technique at the CETIOM laboratory at Ardon.

In 1994, leaf area index determinations were made at the beginning of anthesis (R5 according to Schneiter $\&$ Miller (1981)) by using the non-destructive method of Pouzet \& Bugat (1985). Plants were counted on ten areas of $1 \mathrm{~m}^{2}$ and one median stage plant per quadrat was assessed for leaf area. Symptoms of Phomopsis were observed at the R8 stage on five series of ten successive plants according to the following scale (Pinochet 1994): (0) healthy; (1) non-encircling spot on the stem; (2) encircling spot on the stem; (3) totally brown stem; (4) stem broken at the site of the spot. The number of spots per plant was not counted. A similar approach was used for Phoma macdonaldii Boerema with only two classes (healthy or presence of a dark spot surrounding the petiole).

\section{Statistical analysis}

In 1994, the experiment was a randomized four-block design. As no blocks were available in the 1984-92 period, the four yield replicates within each plot were used to measure variability and crop management $x$ replicates was used as the error term.

\section{Use of crop simulation}

A simulation model of a sunflower crop in rotation was used to assist in a wider agronomic evaluation of the experimental results. The EPIC-Phase model has been successfully validated on sunflower in southwestern France and was adopted for this reason (Quinones et al. 1990; Kiniry et al. 1992). The model simulates the evolution of leaf area index (LAI), above-ground biomass, water use, $\mathrm{N}$ uptake, and rooting pattern in relation to water and nitrogen dynamics in the soil, using a daily time step. Both biomass and harvest index are affected by water and nitrogen stress. A limited number of genotypic characteristics must be provided, such as growing degree-days (GDD) for early bud stage, anthesis and physiological maturity.

As field determinations of mineral nitrogen are extremely variable in space and fluctuate in time, a simulation of nitrate leaching was attempted using the EPIC-Phase model. Validations attempted on the nitrogen sub-model indicated good agreements with reality (Vereecken et al. 1991). As the residual effects of sunflower management should be assessed on the subsequent crop, a sunflower-wheat rotation was simulated using 27 years of climatic data at Auzeville. Sunflower was assumed to have been sown on 15 April and wheat on 15 November of each year. A range of $\mathrm{N}$ amounts at sowing was tested on sunflower $(0,30,60,90,120$ and $150 \mathrm{~kg} / \mathrm{ha})$, while wheat always received $150 \mathrm{~kg} /$ ha split into three spring applications. Two irrigation regimes were tested: two applications of $35 \mathrm{~mm}$ around anthesis, and five applications of $30 \mathrm{~mm}$ every 10 days from the end of June until early August.

\section{Economic evaluation (before and after 1992 CAP regime)}

The calculation of operating costs, crop products and gross margins was attempted using the experimental results. The production costs included seeds, NPK fertilizers, chemicals for crop protection, and fuel. Only energy costs for delivering irrigation were considered; an average value of $0.50 \mathrm{FF} / \mathrm{m}^{3}$ of water supplied was used in the calculations.

A steady decline in prices for the sunflower crop has occurred since 1984: from $3500 \mathrm{FF}$ per ton of grain in 1984 to $<1000 \mathrm{FF}$ in 1992 , with a slight increase after CAP reform (to $1300 \mathrm{FF}$ ). Only slight reductions in unit costs for fertilizers and pesticides were observed. The new statement of EEC Common Agricultural Policy was applied in 1993 with a reduction in prices, the introduction of compensatory subsidies and a compulsory set-aside of $15 \%$ of the arable land.

Three different calculations were made, using the average yield of the 1984-92 period and the corresponding production costs, which integrated the adaptation of practices to climate and to cumulative effects, in a context of relative stability of input costs: (1) average price for 1984-87 (3300 FF per ton at $9 \%$ grain moisture), (2) average price for 1988-91 (2700 FF), and (3) average price for 1992-95 (1200 FF). In this last case, a fixed subsidy of $3500 \mathrm{FF}$ per ha of sunflower was supplied in south-western France, on the condition that $15 \%$ of the farm was set-aside. The net return from a sown set-aside was c. $1500 \mathrm{FF}$ per ha: a subsidy of $2400 \mathrm{FF}$ per ha minus the cost of $900 \mathrm{FF}$ per ha for seeds, weed control and tillage. Assuming a triennial rotation, the actual return from 1 ha of sunflower in the new CAP regime was calculated as $95 \%$ of the sunflower gross margin $+5 \%$ of the set-aside gross margin.

\section{RESULTS}

\section{Climatic conditions and diseases}

The weather variability during the 10 years of experimentation was high (Table 3). In 1984, early sunflower growth was limited by relatively low temperatures in spring, then water availability was reduced during flowering (in July). No Phomopsis was observed in this region.

In 1985, conditions for early growth were favourable. Water shortage was observed during the summer. Numerous fields were affected by Phomopsis in the Toulouse region (Delos \& Moinard 1995). 
Table 5. Sunflower yield response ( $t /$ ha at $0 \%$ grain moisture) as a function of year and crop management scheme (1984-94) for rotations $A$ and $B .^{*} L R=$ low-input rainfed management, $M R=$ medium-input rainfed management, $H R=$ high-input rainfed management, $M I=$ medium-input irrigated management, $H I=h i g h$ input irrigated management

\begin{tabular}{|c|c|c|c|c|c|c|c|c|c|c|c|c|c|}
\hline Rotation* & $\begin{array}{c}\text { Crop } \\
\text { management }\end{array}$ & 1984 & 1985 & 1986 & 1987 & 1988 & 1989 & 1990 & 1991 & 1992 & 1994 & & Mean \\
\hline \multirow[t]{4}{*}{ A } & LR & $3 \cdot 24$ & $3 \cdot 46$ & $2 \cdot 29$ & $2 \cdot 97$ & $3 \cdot 29$ & $3 \cdot 22$ & $1 \cdot 51$ & $1 \cdot 55$ & $1 \cdot 01$ & $2 \cdot 38$ & & $2 \cdot 49$ \\
\hline & MR & $2 \cdot 46$ & 3.09 & $2 \cdot 65$ & $3 \cdot 09$ & $2 \cdot 34$ & $2 \cdot 67$ & $1 \cdot 50$ & $2 \cdot 26$ & $1 \cdot 33$ & 1.92 & & $2 \cdot 33$ \\
\hline & HR & $2 \cdot 29$ & $3 \cdot 33$ & $2 \cdot 49$ & $2 \cdot 89$ & $2 \cdot 91$ & $2 \cdot 53$ & $1 \cdot 13$ & $1 \cdot 74$ & $1 \cdot 03$ & $2 \cdot 46$ & & $2 \cdot 28$ \\
\hline & S.E. (9 D.F.) & $0 \cdot 400$ & $0 \cdot 186$ & $0 \cdot 105$ & $0 \cdot 134$ & $0 \cdot 189$ & $0 \cdot 123$ & $0 \cdot 096$ & $0 \cdot 168$ & $0 \cdot 110$ & $0 \cdot 247$ & S.E. (18 D.F.) & $0 \cdot 139$ \\
\hline \multirow[t]{5}{*}{ B } & LR & $3 \cdot 22$ & $2 \cdot 97$ & $2 \cdot 47$ & $2 \cdot 59$ & $2 \cdot 89$ & 1.92 & $1 \cdot 52$ & $2 \cdot 50$ & $1 \cdot 81$ & $2 \cdot 43$ & & $2 \cdot 43$ \\
\hline & MR & $2 \cdot 43$ & $2 \cdot 73$ & $2 \cdot 56$ & $3 \cdot 13$ & $2 \cdot 57$ & $2 \cdot 23$ & 1.63 & $2 \cdot 77$ & 1.53 & $2 \cdot 30$ & & $2 \cdot 39$ \\
\hline & MI & $3 \cdot 15$ & $3 \cdot 44$ & $3 \cdot 96$ & $3 \cdot 05$ & $2 \cdot 75$ & $2 \cdot 95$ & $2 \cdot 90$ & $2 \cdot 75$ & $1 \cdot 03$ & $2 \cdot 31$ & & $2 \cdot 83$ \\
\hline & HI & $3 \cdot 12$ & $3 \cdot 13$ & 3.99 & $2 \cdot 95$ & $2 \cdot 73$ & $4 \cdot 05$ & $3 \cdot 80$ & $3 \cdot 65$ & $1 \cdot 15$ & $2 \cdot 28$ & & $3 \cdot 08$ \\
\hline & S.E. (12 D.F.) & $0 \cdot 130$ & $0 \cdot 213$ & $0 \cdot 135$ & 0.096 & $0 \cdot 198$ & $0 \cdot 163$ & $0 \cdot 154$ & $0 \cdot 202$ & $0 \cdot 115$ & $0 \cdot 237$ & S.E. (27 D.F.) & $0 \cdot 229$ \\
\hline
\end{tabular}

* See text for details.

In 1986, cold conditions in April affected the emergence of sunflower. The late sowing was then affected by an early drought from June onwards. The spread of Phomopsis to the stems was prevented by the severe water deficit.

In 1987, a normal rainfall pattern was observed and temperatures were favourable to early growth. Release of Phomopsis ascospores was observed from the end of June. This late infection had more effect on yield than in 1986, because summer conditions did not prevent spread to the stems in 1987.

In 1988, winter and spring conditions were very mild and rainy, which explained the very early Phomopsis contamination (early May) and the severity of attacks on stems.

In 1989, there was severe drought from May to September. Contamination by Phomopsis and its spread through the plant were limited by the absence of significant rainfall from May onwards.

In 1990, the soil water profile was not recharged during winter, because of the severe soil deficit in autumn and low rainfall during winter. Mild conditions and normal rainfall in April-May were responsible for early leaf infection, but the persistent drought limited the effect of these attacks.

In 1991, low temperatures delayed the maturation of Phomopsis ascospores and significant infection occurred rather late in the season, as in 1987; then the summer drought and high temperatures limited the spread of Phomopsis within plants.

In 1992, there was very heavy rainfall from June to September, which caused a severe attack of Phomopsis and large yield losses, through stem breakage, in spite of a rather late infection period (early June) (Delos et al. 1995).

In 1994, very wet conditions in spring delayed the sowing period to early May. The growing season was very dry except for the rain at the end of June which caused infection by the release of Phomopsis ascospores (Delos et al. 1995). Sunflower did not suffer from water shortage until anthesis (10-20 July). The occurrence and spread of Phomopsis was limited by the summer drought and the yield losses were reduced, compared with previous years. First symptoms on leaves were observed on 20 July. In spite of the summer drought and high temperatures, spread to the stem was not stopped completely but the percentage of seriously affected stems was relatively low.

In summary; 1986, 1989 and 1990 were considered to be very dry years, the main limiting factor was water availability and Phomopsis had no effects on yields. In 1987, 1988 and 1992, significant yield losses $(0.5,0.7$ and $1.2 \mathrm{t} / \mathrm{ha}$, respectively) (R. A. Perny, personal communication) were observed at a regional level, as a result of early Phomopsis attacks or rainy conditions in summer which favoured the rapid spread of the disease to the stems. In 1984, 1985, 1991 and 1994, no major limiting factors were observed, but slight water deficits and moderate attacks of Phomopsis occurred.

Response of grain yield to increasing management inputs

\section{Dry conditions}

In 1986, 1989 and 1990, under disease-free conditions, far higher yields were observed in rotation B with supplementary irrigation (Table 5). Under the limited irrigation strategy (MI), sunflower yielded $1 \cdot 4$, 0.7 and $1.3 \mathrm{t} /$ ha more than under rainfed management (MR), for 1986, 1989 and 1990, respectively. Full irrigation (HI) was effective for maximum grain production, because of a pronounced water deficit during most of the growing season. The corresponding yield increases were $1 \cdot 4,1 \cdot 8$ and $2 \cdot 2 \mathrm{t}$ / ha as compared 


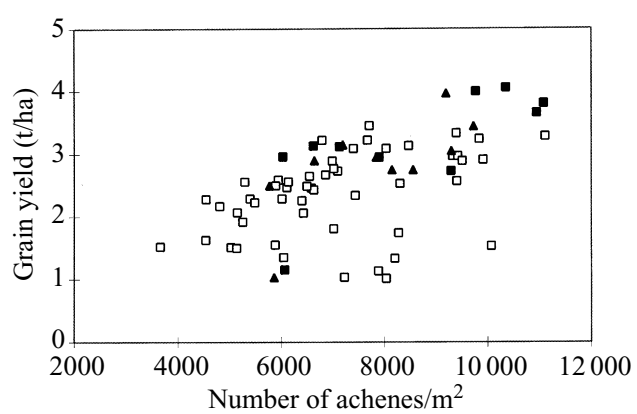

Fig. 1. Grain yield (t/ha) of sunflower as related to achene number $/ \mathrm{m}^{2}$ for different management options: HI, Highinput, fully irrigated (ם); MI, medium-input, moderately irrigated $(\mathbf{\Delta}) ; \mathrm{MR}+\mathrm{LR}$, Low- and Medium-input, rainfed $(\square)$.

with MR. The best yields (up to $4 \cdot 0 \mathrm{t} / \mathrm{ha}$ ) were observed in dry years under full irrigation, as a result of high irradiance and low disease incidence. In 1986, HI treatment received $170 \mathrm{~mm}$ irrigation split into five applications from 16 June to 7 August while MI received three applications $(110 \mathrm{~mm})$ between 29 June and 28 July, but there was no significant yield difference between the two irrigation strategies in spite of the severe shortage of rain (Table 3). As drought occurred only in June and as the soil water reserve was recharged at sunflower emergence, a limited irrigation supply was enough in 1986 on deep soils, in view of the considerable ability of sunflower to extract water from deep layers.

In 1989, $160 \mathrm{~mm}$ was supplied on HI between 14 June and 29 July while MI received $120 \mathrm{~mm}$ between 22 June and 20 July. In 1990, the corresponding irrigations were $150 \mathrm{~mm}$ on HI (27 June to 20 July) and $90 \mathrm{~mm}$ on MI (2 to 19 July). The early and severe drought of 1989 and the absence of soil water recharge during winter in 1990 explain the increase of yield with water supply from MR to HI under disease-free conditions.

In 1991, $110 \mathrm{~mm}$ was supplied in HI just before (6 July) and after flowering (28 July) while $80 \mathrm{~mm}$ was applied at the beginning of grain-filling in MI. Two applications around flowering gave the best result in 1991 (HI), while late applications were not effective compared with rainfed management. In the absence of early and severe drought, there was no advantage of full irrigation programmes for maximizing grain yield on deep soils.

In rotation $\mathrm{A}$, the $\mathrm{HR}$ management had the lowest yields, indicating that increasing inputs (plant population, $\mathrm{N}$ fertilization) without irrigation was not appropriate in very dry years (Table 5). A substantial yield reduction was observed in 1990 while in 1986 and 1989, rainfed production was moderately affected. As drought occurred before flower bud (R1 stage), plant drought adaptation was observed in 1986 and
1989 (leaf area reduction, higher harvest index), as described by Blanchet et al. (1990). In 1990, rainfall after sowing was responsible for the rapid growth until R1, increasing leaf area index and water requirements; as no drought adaptation was possible in such conditions, sunflower suffered greatly from the reduced summer rainfall and from the absence of deep water. In 1984, spring conditions stimulated crop growth and leaf area expansion: the water shortage in July affected HR and MR more than LR. In deep soils, there is a need to limit green leaf area, and thus water requirements, early enough to prevent such rapid leaf senescence from anthesis onwards. Merrien \& Grandin (1990) showed that the maximum yield was obtained with a ratio of actual evapotranspiration:potential evapotranspiration of 0.74 over the whole growing period; the optimal value was 0.69 for the 'emergence-beginning of flowering' period, 0.80 for the flowering period, and 0.74 for the grain-filling period. These ratios should be used as intermediary management goals.

\section{Wet years}

In 1988, the production of sunflower under LR without fungicide was slightly higher than the one under HR with fungicide, but a susceptible genotype (cv. Viki) was used for all management options (Table 5). In 1992, as continuous rain prevented any fungicide application during the appropriate period (before $\mathrm{R} 1$ ), reducing inputs for sunflower increased yields on LR and MR for rotation B, while the susceptible cultivar Viki was grown on HR and HI systems. However, the use of a tolerant genotype such as Select in 1992 had only limited effects on yield loss, probably because of persistent humidity and the amount of inoculum in soils.

In years when Phomopsis affected the crop less seriously (as in 1985, 1987, 1991 and 1994), yields under the unsprayed LR management did not differ significantly from HR.

\section{Overall}

In rotation A, significantly higher or equivalent yields were found for LR as compared with MR management in seven years out of ten. For nine of the ten years, higher or equivalent yields were found for LR as opposed to HR management. Higher or equivalent yields were found for MR than for HR management in eight years out of ten. In rainfed conditions, there is evidence of a limited response of sunflower to increasing the amount of inputs.

In rotation $\mathrm{B}$, significantly higher or equivalent yields were found for LR than for MR management in seven years out of ten. In five years out of ten, grain yield under LR was greater than or equivalent to MI and HI management. It was the same for MR. Equivalent yields were found for MI and HI management in six years out of ten. Limited irrigation for 


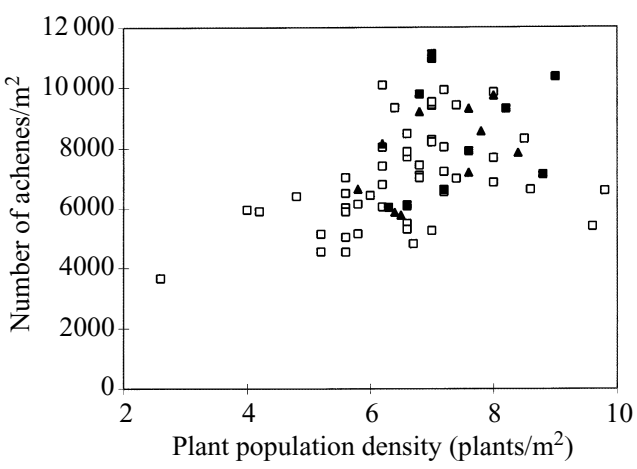

Fig. 2. Achene number $/ \mathrm{m}^{2}$ of sunflower as related to plant population density (plants $/ \mathrm{m}^{2}$ ) for different management options: HI, High-input, fully irrigated (ם); MI, Mediuminput, moderately irrigated $(\boldsymbol{\Delta}) ; \mathrm{MR}+\mathrm{LR}$, Low- and Medium-input, rainfed ( $\square$ ).

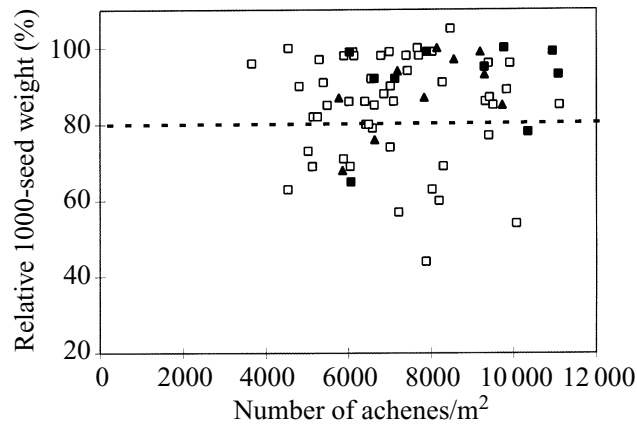

Fig. 3. Relative 1000 -seed weight ( $\%$ of reference 1000 -seed weight) of sunflower as related to achene number $/ \mathrm{m}^{2}$ for different management options: HI, High-input, fully irrigated (ם); MI, Medium-input, moderately irrigated ( $\boldsymbol{(})$; MR + LR, Low- and medium-input, rainfed $(\square)$.

sunflower appeared to be an effective way to secure yields. But in half the years, the limitation of water use could be achieved by low-input management in the case of deep soils.

\section{Diagnosis using yield components}

In the absence of limiting factors or when drought occurred before anthesis, grain yield and achene number $/ \mathrm{m}^{2}$ were positively related, as in most grain crops (Fig. 1) and achene number increased with plant population over the range $2 \cdot 5-7 \cdot 5$ plants $/ \mathrm{m}^{2}$ (Fig. 2). Problems at emergence (e.g. slugs) seriously limit potential crop production in sunflower, but when drought occurred early, as in 1989 and 1990, the achene number was decreased by water stress during the vegetative and flowering periods. In 1984, too high densities were responsible for the rapid soil water depletion and water stress at flowering, which reduced achene production. This is obviously a less reliable way to manage sunflower under rainfed conditions.

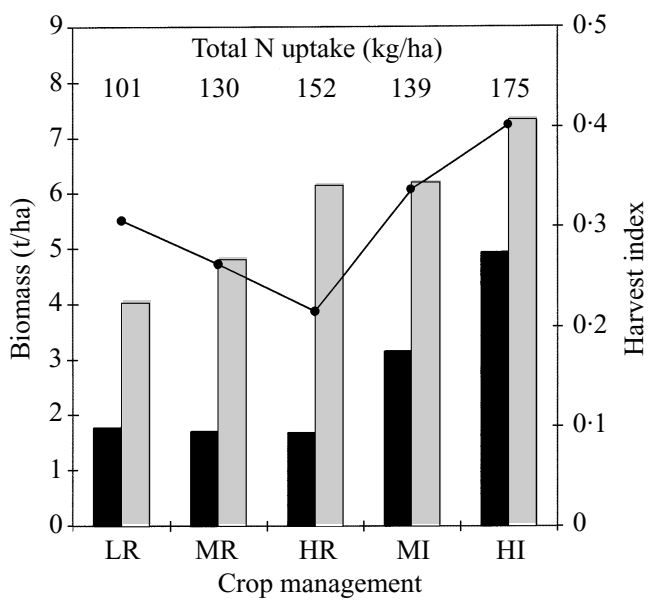

Fig. 4. Grain yield ( $\mathbf{\square}, \mathrm{t} / \mathrm{ha}$ ), vegetative biomass at maturity (圆, t/ha), and harvest index (O) of sunflower as related to crop management in 1990. Labels indicate the values of total $\mathrm{N}$ uptake (grain + shoot) at maturity.

Much compensation in seed weight is generally observed in current conditions of sunflower cropping, as high 1000 -seed weight can be maintained with high achene number $/ \mathrm{m}^{2}$ (Blanchet 1994). The seed weight was expressed as a percentage of potential seed weight because of some genotypic differences (Table 2). Over the range 3000-12000 achenes $/ \mathrm{m}^{2}$, potential 1000 seed weight can be obtained, in the absence of stressful environmental conditions during grain-filling (Fig. 3). In 1992, as Phomopsis attacks were extremely severe and resulted in high proportions of stem breakage (20-30\%) and grain shrivelling, only 50$70 \%$ of the potential seed weight was observed, but better results were obtained with tolerant genotypes (LR and MR). In 1990, the severe soil water deficit reduced the duration of grain-filling under rainfed management by accelerating foliar senescence, while post-flowering irrigation delayed canopy senescence. Shoot biomass increased with $\mathrm{N}$ fertilization and $\mathrm{N}$ uptake over the range of treatments, but harvest index was reduced under rainfed management as a result of soil water depletion, leading to a different grain yield ranking (Fig. 4).

\section{Response of oil production to increasing crop intensification}

Oil concentration and grain yield increased together (Fig. 5), while oil and protein concentrations were negatively related (data not shown). The HI management proved best for securing an oil concentration $>50 \%$. More variable results were observed under rainfed management and even under limited irrigation. Sufficient water is necessary during grainfilling to achieve a high oil concentration (Picq \& Abramovsky 1989; Ouattar et al. 1992). The type of 


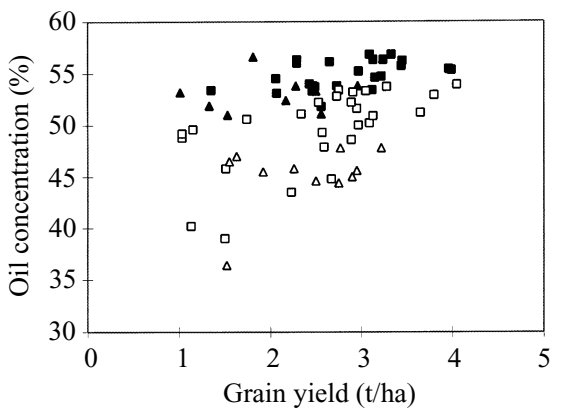

Fig. 5. Oil concentration (\%) of sunflower grain as related to grain yield $(\mathrm{t} / \mathrm{ha})$ for different irrigation strategies and different genotypes (cv. Topflor, ( $\mathbf{\square})$; cv. Select, $(\boldsymbol{\Delta})$; cv. Viki, $(\square)$; cvs Agrisol + TN 15+Frankasol $\triangle$ ).

genotype contributed to the oil quality (Table 2). Genotypes such as cv. Topflor or cv. Select had higher oil concentrations over a wide range of grain yields and related crop managements (Fig. 5). Phomopsis attacks for cv. Viki and drought for cv. Agrisol and $\mathrm{TN} 15$, which accelerates senescence, decreased oil concentration to $35-40 \%$ in such genotypes. This is consistent with the results of Acimovic (1986) and Penaud et al. (1994) who observed a reduction of $25-30 \%$ of oil concentration in presence of severe attacks of Phomopsis.

\section{Phomopsis and Phoma attacks as related to crop management}

In 1994, the percentage of plants not affected by Phomopsis was lower under LR and HR management than under MR, MI and HI (Table 6). Irrigation enhanced Phomopsis infection without fungicide ap-

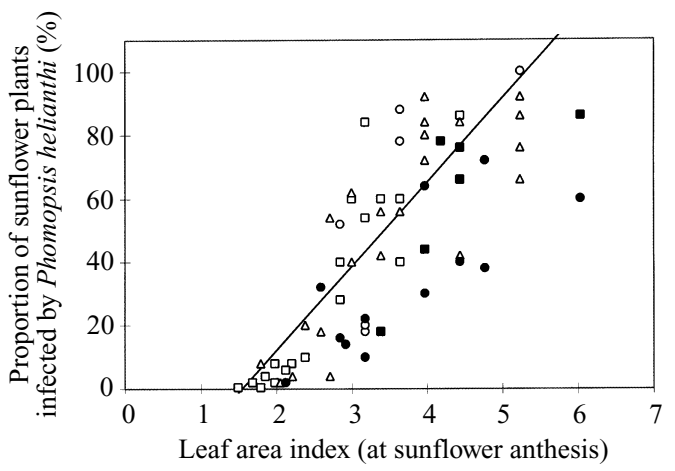

Fig. 6. Proportion of sunflower plants infected by Phomopsis helianthi $(\%)$ as a function of leaf area index at the beginning of the flowering period: HI, High-input, fully irrigated, fungicide-sprayed (ם); HR, High-input, rainfed, fungicidesprayed (O); MI, Medium-input, moderately irrigated, unsprayed $(\bigcirc)$; Medium-input, rainfed, unsprayed $(\triangle)$; Low-input, rainfed, unsprayed ( $\square$ ). $Y=26 \cdot 5 X-40 \cdot 9, r^{2}=0 \cdot 740(n=52)$.

plication (MR v. MI) and even with fungicide (HR v. HI). Low-input management, by limiting the leaf area index (LAI) and reducing the humidity under the canopy, reduced the incidence of Phomopsis. The proportion of plants infected by Phomopsis was reasonably correlated with leaf area index at anthesis for unsprayed situations, i.e. LR, MR and MI (Fig. 6). For a given value of LAI, fungicide-treated plots (HR and $\mathrm{HI}$ ) were less infected by the disease. In spite of low-input management, a range of LAI values was observed under LR management (from 1.5 to $4 \cdot 5$ ), indicating the predominant influence of cropping history in deep soils on vegetative growth. According to Pinochet (1994), the percentage of harmful symp-

Table 6. Symptoms of Phomopsis helianthi and Phoma macdonaldii attacks (in \% of plants) as related to sunflower crop management (cv. Select, 1994). LR = low-input rainfed management, $M R=$ medium-input rainfed management, $H R=$ high-input rainfed management, $M I=$ medium-input irrigated management, $H I=h i g h$ input irrigated management. Scale of disease survey: $(0)$ healthy; (1) non-encircling spot on the stem; $(2)$ encircling spot on the stem; (3) totally brown stem; (4) stem broken at the spot; ( $\geqslant 2$ ) harmful symptoms

\begin{tabular}{|c|c|c|c|c|c|c|c|c|c|c|c|}
\hline \multirow[b]{2}{*}{ Treatments } & \multirow{2}{*}{$\begin{array}{l}\text { Fungicide } \\
\text { application }\end{array}$} & \multirow{2}{*}{$\begin{array}{c}\text { Plot } \\
\text { number }\end{array}$} & & \multirow{2}{*}{$\begin{array}{l}\text { Leaf area } \\
\text { index at } \\
\text { anthesis }\end{array}$} & \multicolumn{6}{|c|}{ Symptoms of Phomopsis } & \multirow{2}{*}{$\begin{array}{c}\text { Phoma } \\
1\end{array}$} \\
\hline & & & & & 0 & 1 & 2 & 3 & 4 & $\geqslant 2$ & \\
\hline \multirow[t]{2}{*}{ LR } & 0 & 20 & Mean & $2 \cdot 70$ & $68 \cdot 5$ & $22 \cdot 2$ & 1.9 & $7 \cdot 2$ & $0 \cdot 2$ & $9 \cdot 3$ & $17 \cdot 1$ \\
\hline & & & S.E. mean & $0 \cdot 200$ & $6 \cdot 95$ & $4 \cdot 98$ & $0 \cdot 67$ & $1 \cdot 83$ & $0 \cdot 14$ & $2 \cdot 33$ & $3 \cdot 10$ \\
\hline \multirow{2}{*}{ MR } & 0 & 22 & Mean & $3 \cdot 57$ & $48 \cdot 5$ & $30 \cdot 8$ & $4 \cdot 1$ & $14 \cdot 9$ & 1.7 & $20 \cdot 7$ & $26 \cdot 8$ \\
\hline & & & S.E. mean & $0 \cdot 233$ & $6 \cdot 58$ & $4 \cdot 19$ & 1.53 & $2 \cdot 53$ & $0 \cdot 51$ & $2 \cdot 91$ & $3 \cdot 91$ \\
\hline \multirow[t]{2}{*}{ MI } & 0 & 6 & Mean & $3 \cdot 62$ & $41 \cdot 0$ & $31 \cdot 0$ & $6 \cdot 7$ & $20 \cdot 0$ & $1 \cdot 3$ & $28 \cdot 0$ & $20 \cdot 3$ \\
\hline & & & S.E. mean & $0 \cdot 347$ & $14 \cdot 34$ & $4 \cdot 52$ & $2 \cdot 40$ & $8 \cdot 39$ & $0 \cdot 84$ & $11 \cdot 33$ & $3 \cdot 70$ \\
\hline \multirow[t]{2}{*}{ HR } & 1 & 12 & Mean & $3 \cdot 73$ & $66 \cdot 7$ & $21 \cdot 3$ & $1 \cdot 8$ & $8 \cdot 7$ & $1 \cdot 5$ & $12 \cdot 0$ & $15 \cdot 3$ \\
\hline & & & S.E. mean & $0 \cdot 326$ & $6 \cdot 49$ & $5 \cdot 01$ & $0 \cdot 72$ & $2 \cdot 06$ & $0 \cdot 70$ & $2 \cdot 39$ & 3.97 \\
\hline \multirow[t]{2}{*}{ HI } & 1 & 6 & Mean & $4 \cdot 41$ & $38 \cdot 7$ & $38 \cdot 7$ & $2 \cdot 7$ & $15 \cdot 3$ & $4 \cdot 7$ & $22 \cdot 7$ & $26 \cdot 3$ \\
\hline & & & S.E. mean & $0 \cdot 362$ & $10 \cdot 49$ & $6 \cdot 23$ & $1 \cdot 23$ & $4 \cdot 81$ & $1 \cdot 43$ & $5 \cdot 97$ & $5 \cdot 67$ \\
\hline
\end{tabular}


Table 7. Simulation of sunflower yield response to $N$ application under different irrigation strategies (1970-96)

\begin{tabular}{|c|c|c|c|c|c|c|}
\hline \multirow{2}{*}{$\begin{array}{l}\mathrm{N} \text { rate } \\
(\mathrm{kg} / \mathrm{ha})\end{array}$} & \multirow[b]{2}{*}{ Rainfed } & \multicolumn{2}{|c|}{ Irrigated } & \multirow[b]{2}{*}{ Rainfed } & \multicolumn{2}{|c|}{ Irrigated } \\
\hline & & $70 \mathrm{~mm}$ & $150 \mathrm{~mm}$ & & $70 \mathrm{~mm}$ & $150 \mathrm{~mm}$ \\
\hline 0 & $2 \cdot 47$ & $2 \cdot 57$ & 2.63 & 17 & 17 & 17 \\
\hline 90 & $3 \cdot 03$ & $3 \cdot 30$ & $3 \cdot 48$ & $24 \cdot 5$ & 25 & $25 \cdot 5$ \\
\hline 120 & $3 \cdot 02$ & $3 \cdot 30$ & $3 \cdot 48$ & 30 & 31 & 33 \\
\hline 150 & $3 \cdot 02$ & $3 \cdot 30$ & $3 \cdot 48$ & 35 & $37 \cdot 5$ & 40 \\
\hline
\end{tabular}

toms would lead to a yield loss of $0 \cdot 2-0.5 \mathrm{t} / \mathrm{ha}$, which is consistent with the difference between MR and HR in rotation A (fungicide effect).

The percentage of plants infected by Phoma was smaller, probably because of the competition with Phomopsis. LR and HR management appeared to be the least affected by this disease.

Diseases, mainly Phomopsis helianthi in this experiment, were favoured by higher plant density and superabundant $\mathrm{N}$ supply, as was used in the HR and HI management schemes. This could explain the relative success of LR management in 1987 and 1988. The use of Phomopsis-tolerant genotypes such as cv. Select did not completely prevent the infection by the disease but emphasised the role of crop management, because $0-100 \%$ of the stems were attacked under the unsprayed management according to the density and $\mathrm{N}$ status of the crop canopy. These results suggest the possible value of integrated crop protection methods in the control of sunflower diseases (Jinga et al. 1992).

\section{Residual effects of sunflower management}

Soil water deficit at harvest

Soil water deficit at sunflower harvest was important when compared with other crops (Debaeke \& Cabelguenne 1994). Under MR management, only $7 \%$ of the soil water reserve $(285 \mathrm{~mm}$ over $150 \mathrm{~cm}$ depth) was available for the next crop (average of the 1985-91 period); under MI and HI, the corresponding values were 16 and $35 \%$. Deep water extraction is generally observed in sunflower (Maertens \& Cabelguenne 1974). The overwinter soil water recharge, especially for the deep layers, could be affected by the severe soil desiccation after rainfed or moderately irrigated treatments. Compared with irrigated maize, less water percolation in autumn is expected after sunflower, and particularly under lowinput management.

\section{Nitrogen leaching}

The annual amount of $\mathrm{N}$ leaching, simulated by EPICPhase, ranged from 17 to $40 \mathrm{~kg} /$ ha depending on the
$\mathrm{N}$ amount and irrigation volume (Table 7). Abundant $\mathrm{N}$ fertilization in sunflower was more responsible for high $\mathrm{N}$ leaching than supplementary irrigation. The average $\mathrm{N}$ leaching doubled from LR to HI management. The sunflower-wheat rotation probably presents little risk to the environment as regards nitrogen losses under rainfed production. In deep soils, the amount of residual nitrogen available for subsequent wheat growth can be large, especially after dry seasons and under high-input sunflower management (Debaeke et al. 1996).

The increase of $\mathrm{N}$ leaching above a fertilizer rate of $60 \mathrm{~kg} / \mathrm{ha}$ was associated with the low $\mathrm{N}$ uptake and limited response of grain yield to N fertilizer. In 1994, the experimental response of grain yield to nitrogen application was not significant: $2.45(0 \mathrm{~N}) v .2 .55 \mathrm{t} / \mathrm{ha}$ $(\mathrm{N})$ in rotation $\mathrm{A}, 2.49(0 \mathrm{~N}) v .2 .57 \mathrm{t} / \mathrm{ha}(\mathrm{N})$ in rotation $\mathrm{B}$, suggesting high residual nitrogen but also the considerable ability of sunflower to extract nitrogen from the deepest layers, which makes sunflower a depolluting crop (Blanchet et al. 1987). In addition, more symptoms of Phomopsis attacks were recorded on $\mathrm{N}$-fertilized plots. The prior simulation could not predict the effect of $\mathrm{N}$ fertilization on disease infection; but, using this assumption, the yield difference between $0 \mathrm{~N}$ and $60 \mathrm{~N}$ ranged from 0 to 1.4 $\mathrm{t} / \mathrm{ha}$, and in half the years the response was $<0.5$ t/ha. As shown by Merrien et al. (1988), the actual N fertilizer use was c. $25-30 \%$ : so most of the nitrogen uptake by sunflower comes from the soil mineralization and residual nitrogen. $\mathrm{N}$ uptake was far greater than $\mathrm{N}$-fertilizer supply in sunflower, even in low-input cropping systems since 1984.

\section{Economic return}

\section{Operating costs}

The cost of inputs used on sunflower more than doubled from LR (1100 FF/ha) to HR and HI management (2600 FF/ha). When including the energy costs (fuel, irrigation pumping), the production costs ranged from $1400 \mathrm{FF} /$ ha (LR) to $3700 /$ ha (HI). On this basis, $540 \mathrm{FF}$ were needed to produce one ton 


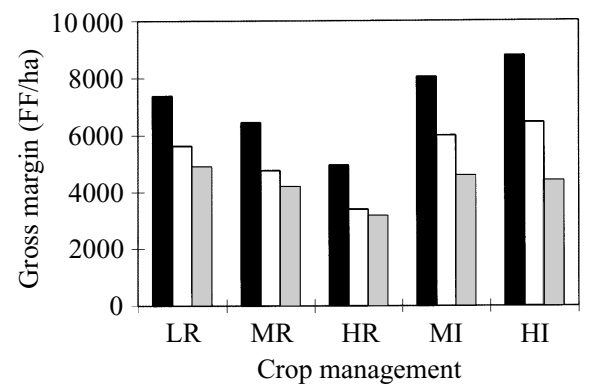

Fig. 7. Sunflower gross margin (FF/ha) for different management options and different price assumptions

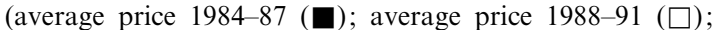
new CAP average price 1992-95 (圆)).

of commercial grain under LR, $810 \mathrm{FF}$ under MR, $880 \mathrm{FF}$ under MI, $1060 \mathrm{FF}$ under $\mathrm{HI}$, and $1240 \mathrm{FF}$ under HR.

\section{Gross margin}

The decrease of gross margin (GM) was marked in the periods 1988-91 and 1992-95 as compared with the favourable price period of 1984-97 (Fig. 7). GM decreased by $35 \%$ under rainfed management and by $50 \%$ under full irrigation management $(\mathrm{HI})$.

With favourable prices, irrigated systems were the most profitable. Under the new CAP regime, GM was slightly better under LR than under MI or HI management. In irrigated systems, increasing irrigation amount and related inputs (nitrogen, crop protection) was no more profitable. The possible increase of water cost would emphasise this trend. Increasing inputs (nitrogen, crop density, crop protection) under rainfed conditions was never a good economic strategy on deep soils, in the absence of yield increase and sometimes with depressive effects (Blanchet et al. 1987). With the new CAP, the differences between GM among management systems were less pronounced than before, because of the buffering effect of subsidies. LR and MI management should be the only economic forms in the new situation.

\section{DISCUSSION}

This research demonstrated that low-input production for dryland and medium-input with limited irrigation for irrigated land are feasible in south-western France with respect to agronomic and economic constraints. Reducing the use of inputs on sunflower is agronomically sound as the crop has moderate cultivation requirements and is not very responsive to major production inputs. This is especially true in deep soils where the taproot system is efficient enough to extract nutrients and water down to the deeper layers (Blanchet et al. 1987). By reducing $\mathrm{N}$ supply and plant population density, leaf area expansion can be prevented sufficiently to avoid excessive soil water depletion, risks of diseases, lodging and early senescence as a result of self-shading (Merrien 1992). Controlling vegetative growth in this way is risky: as was shown in Fig. 6, leaf area index may vary greatly among low-input plots. Nitrogen which will become available over the rooting depth cannot be easily assessed at sowing time and limiting crop density is a risky decision in conditions of early sowing, low temperatures and drought. In any event, in the conditions of south-western France, there is no evidence of a far higher yield variability between years for low-input cropping systems managed without irrigation.

Results from other parts of France (Wagner \& Leterme 1993; Reau \& Wagner 1994) and from Italy (Rinaldi et al. 1992; Bonari et al. 1996) confirmed the absence of a systematic response of grain yield to input increases. This was especially true when no major limiting factors occurred during the growing season. But when Phomopsis attacks were severe (Reau \& Wagner 1994) or when drought prevailed (Bonari et al. 1996), intensive crop management using fungicides and/or supplementary irrigation gave the best yields and generally the best return, because of sharp yield losses under low-input management. The frequency of such events in a given situation should explain the ranking of the different management strategies.

A benefit to the environment could be expected from limiting the nitrogen supply for sunflower (Table 7). Long-term effects of reducing inputs during two rotation courses have not been assessed in this contribution. No harmful effects have been observed in respect of weeds or soil organic nitrogen in the rotations where sunflower was grown (data not shown). The limitation of pesticides in LR should be a strong argument for this option.

On irrigated farms, irrigation is primarily applied to maize. Supplementary irrigation around anthesis would increase yield production by $0.7-1.4 \mathrm{t} / \mathrm{ha}$ in dry situations (Table 5). In the deep soils of Auzeville, $c$. $100 \mathrm{~mm}$ of irrigation, split into two or three applications around flowering, appeared to be a good strategy to maximize irrigation efficiency, provided that the soil water reservoir was recharged when the sunflower was sown and that summer drought was not as extreme as in 1989. But as the response of sunflower to water applied is lower than for maize or soyabean (Cabelguenne et al. 1982), this crop is more often cultivated in rainfed situations. Transferring one or two irrigations from maize to sunflower is generally not profitable at the farm level (Deumier et al. 1995).

The adoption of the CAP reform in 1993 reinforced the value of low-input crop management for sunflower. Though the future direction of the CAP is still uncertain, a further decrease in prices is possible, thus favouring the spread of low-input management and 
of crops requiring only limited applications of nitrogen and pesticides. As the size of farms is increasing in the great plains of Europe, there is also some opportunity for management options which limit the working time per hectare.

If low-input systems have been promoted by the economic situation, they also present real environmental advantages, such as reducing the risk of chemical pollution. More effort should be applied to devise integrated cropping systems for sunflower, first by a proper combination of techniques at sowing time, then by the choice of less aggressive herbicides or by mechanical weeding. The reduction of year-toyear variability should be achieved through the choice of genotypes more tolerant to drought and diseases, but also through an appropriate adjustment of techniques (sowing date, crop density, $\mathrm{N}$ fertilization) to accessible grain yields and/or quality goals. Therefore, crop managers will need more time to observe the crop in the field, but they will be assisted by new technologies in the domain of crop diagnosis and agricultural engineering.

The long-term experiment, which included a wide variety of cropping systems and climatic sequences, was useful for evaluating various sunflower management strategies, but the economic results may not apply exactly in the complexity of an actual farm situation. Also, more effort should be devoted to defining decision rules adapted to objectives in order to refine management schemes and make recommendations more adaptable.

The use of crop simulation models should help in interpreting the complex and contradictory crop responses to management schemes. This is especially important in a systems approach. Models should also assist the agronomist in devising innovative management schemes (Meinke et al. 1993). As modelling is constantly developing, we suggest that the next step should be the prediction of the risk of diseases according to crop management and environmental conditions and the resulting yield loss.

The authors acknowledge the assistance of the technical staff of INRA, Agronomy Station, especially M. Dabasse, O. Girotto and P. Petibon, and of D. Ribailler (CETIOM) who kindly carried out the chemical analysis. The advice and contributions of $\mathrm{R}$. Blanchet and J. R. Marty during the planning of the project were also extremely helpful. Financial and technical support were provided by CETIOM, CRAMP and ITCF.

\section{REFERENCES}

Acimovic, M. (1986). The effect of Phomopsis sp. infection on grain yield and oil content of sunflower plants. Helia $\mathbf{9}$, 73-76.

Alessi, J., Power, J. F. \& Zimmerman, D. C. (1977). Sunflower yield and water use as influenced by planting date, population, and row spacing. Agronomy Journal 69, 465-469.

BlanChET, R. (1994). Ecophysiologie et élaboration du rendement du tournesol. Principaux caractères. In Elaboration du Rendement des Principales Cultures Annuelles (Eds L. Combe \& D. Picard), pp. 87-99. Paris, France: INRA Editions.

Blanchet, R., Thomas, G. \& Gelfi, N. (1987). Influence de l'alimentation azotée sur le nombre d'akènes et le rendement du tournesol (Helianthus annuus L., cv. Pharaon) dans différentes situations hydriques. Agricoltura Mediterranea 118, 111-123.

Blanchet, R., Texier, V., Gelfi, N. \& Viguier, P. (1990). Articulations des divers processus d'adaptation à la sécheresse et comportements globaux du tournesol. In $\mathrm{Le}$ Tournesol et l'Eau (Eds R. Blanchet \& A. Merrien), pp. 45-55. Paris, France: CETIOM.

Bonari, E., Silvestri, N. \& Mazzoncini, M. (1996). La diminution des intrants dans la culture de tournesol: premiers résultats d'une recherche faite en Italie Centrale. In Proceedings of the $14^{\text {th }}$ International Sunflower Conference, Beijing, China, 12-20 June 1996, pp. 327-332. Paris, France: International Sunflower Association.
Cabelguenne, M. \& Marty, J. R. (1983). Perspectives sur la place du tournesol dans les assolements du Sud-Ouest de la France. Informations Techniques Cetiom 84, 1-17.

Cabelguenne, M., Marty, J. R. \& Hilaire, A. (1982). Comparaison technico-économique de la valorisaton de l'irrigation par 4 cultures d'été (maïs, soja, sorgho, tournesol). Agronomie 2, 567-576.

Capillon, A. \& Fleury, A. (1986). Conception d'itinéraires techniques respectant la diversité des exploitations agricoles: les enseignements d'un essai. Bulletin Technique d'Information du Ministère de l'Agriculture 408, 281-294.

Debaeke, P. \& Cabelguenne, M. (1994). Influence of previous crop on available water for a subsequent winter wheat on a deep silty clay soil. In Proceedings of the $3^{\text {rd }}$ European Society of Agronomy Congress, Abano-Padova, Italy, 18-22 September 1994 (Eds M. Borin \& M. Sattin), pp. 682-683. Colmar, France: European Society of Agronomy.

Debaeke, P. \& Hilaire, A. (1991). Etude expérimentale de systèmes de culture extensifs et modèles de simulation. In L'extensification, une forme de modernisation. Dijon, France, 23-24 October 1990, pp. 136-146. Paris, France: CIFAR.

Debaeke, P. \& Hilaire, A. (1997). Production of rainfed and irrigated crops under different crop rotations and input levels in southwestern France. Canadian Journal of Plant Science, 77, 539-548.

Debaeke, P., Aussenac, T., Fabre, J. L., Hilaire, A., 
Pujol, B. \& Thuries, L. (1996). Grain nitrogen content of winter bread wheat (Triticum aestivum L.) as related to crop management and to the previous crop. European Journal of Agronomy 5, 273-286.

Deibert, E. J. (1989). Reduced tillage system influence on yield of sunflower hybrids. Agronomy Journal 81, 274-279.

Delos, M. \& Moinard, J. (1995). Evolution du Phomopsis du tournesol en France. Un bref historique. Phytoma 473, 22-24.

Delos, M., Moinard, J. \& Jacquin, D. (1995). Etude et surveillance du Phomopsis. Des pièges au modèle. Phytoma 473, 25-27.

Deumier, J. M., Balas, B. \& Bouthier, A. (1995). Quel assolement, quelle stratégie d'irrigation? Perspectives Agricoles 200, 96-103.

Dixon, F. L. \& Lutman, P. J. W. (1992). Effects of drilling date on the growth and yield of sunflower (Helianthus annuus) in the UK. Journal of Agricultural Science, Cambridge, 119, 197-204.

Gimeno, V., Fernández Martínez, J. M. \& Fereres, E. (1989). Winter planting as a means of drought escape in sunflower. Field Crops Research 22, 307-316.

Jinga, V., Iliescu, H., Ionita, A., Csep, N. \& Iordache, E. (1992). Technological factors in the integrated control of sunflower diseases. In Proceedings of the $13^{\text {th }}$ International Sunflower Conference, Pisa, Italy, 7-11 September 1992, pp. 761-766. Toowoomba, Australia: International Sunflower Association.

Kiniry, J. R., Blanchet, R., Williams, J. R., Texier, V., Jones, C. A. \& Cabelguenne, M. (1992). Sunflower simulation using the EPIC and ALMANAC models. Field Crops Research 30, 403-423.

Maertens, C. \& CABelguenne, M. (1974). Intensité et limite de dessèchement du sol en relation avec l'enracinement de quelques espèces végétales cultivées. Comptes-Rendus de l'Académie des Sciences, Paris 279, 2039-2042.

Meinke, H., Hammer, G. L. \& Chapman, S. C. (1993). A sunflower simulation model: II. Simulating production risks in a variable sub-tropical environment. Agronomy Journal 85, 735-742.

Merrien, A. (1992). Some aspects of sunflower crop physiology. In Proceedings of the $13^{\text {th }}$ International Sunflower Conference, Pisa, Italy, 7-11 September 1992, pp. 481-498. Toowoomba, Australia: International Sunflower Association.

MerRiEn, A. \& Grandin, L. (1990). Comportement hydrique du tournesol. Synthèse des essais "Irrigation" 1983-1988. In Le Tournesol et l'Eau (Eds R. Blanchet \& A. Merrien), pp. 75-90. Paris, France: CETIOM.

Merrien, A., Estragnat, A., Maisonneuve, C. \& Pierre, M. (1988). Coefficient réel d'utilisation de l'azote chez le tournesol: conséquences agronomiques. In Proceedings of the $12^{\text {th }}$ International Sunflower Conference, Novi-Sad, Yugoslavia, 25-29 July 1988, pp. 247-253. Novi-Sad, Yugoslavia: Yugoslav Association of Producers of Plant Oil and Fats and International Sunflower Association.

Metson, A. J. (1956). Methods of chemical analysis for soil survey samples. New Zealand Soil Bureau Bulletin 12.

Meynard, J. M. (1985). Construction d'itinéraires techniques pour la conduite du blé d'hiver. Thesis, Institut National Agronomique Paris-Grignon.

Olsen, S. R., Cole, C. V., Watanabe, F. S. \& Dean, L. A. (1954). Estimation of available phosphorus in soil by extraction with sodium bicarbonate. US Department of Agriculture Circular 939-8.

Ouattar, S., El Asri, M., Lhatoute, B. \& Lahlou, O. (1992). Effet du régime hydrique sur la productivité et la teneur en huile du tournesol. Cahiers Agricultures 1, 173-179.

Penaud, A., Péres, A. \& Regnault, Y. (1994). Rappels sur la maladie. In Le Phomopsis du Tournesol, Oléoscope, $N^{o}$ Spécial 14 (Ed R. Le Page), pp. 15-26. Paris, France: CETIOM.

PicQ, G. \& Abramovsky, P. (1989). Indicateurs et conditions de croissance associés à la teneur et au rendement en huile et en protéines des akènes de tournesol. Informations Techniques Cetiom 108, 18-29.

Pinochet, X. (1994). Phomopsis et évaluation variétale de la sensibilité. In Le Phomopsis du Tournesol, Oléoscope, $N^{o}$ Spécial 14 (Ed R. Le Page), pp. 27-36, Paris, France: CETIOM.

Poiret, M. (1996). Maîtrise de la production et conduite économique pour les grandes cultures. In Bilan de trois années d'application de la réforme. Agreste, les Cahiers du SCEES 1/2, 37-45.

Pouzet, A. \& Bugat, F. (1985). Description d'une méthode simple et rapide pour l'estimation de la surface foliaire par plante chez le tournesol. In Proceedings of the $11^{\text {th }}$ International Sunflower Conference, Mar del Plata, Argentina, 10-13 March 1985, pp. 21-26. Buenos Aires, Argentina: Asociacion Argentina de Girasol (ASAGIR).

Quaglietta Chiarandà, F. \& D’Andria, R. (1994). Effect of different irrigation scheduling on yield and water uptake of a spring sunflower crop (Helianthus annuus L.). European Journal of Agronomy 3, 53-61.

Quinones, H., Texier, V., Cabelguenne, M. \& Blanchet, R. (1990). Simulation du comportement hydrique du tournesol et de ses repercussions sur la croissance et la production. In Le Tournesol et l'Eau (Eds R. Blanchet \& A. Merrien), pp. 56-74. Paris, France: CETIOM.

Reau, R. \& Wagner, D. (1994). Comparaison technicoéconomique de conduites de culture du tournesol. Oléoscope 20, 23-24.

Rellier, J. P. (1981). Analyse statistique des rendements et composantes du rendement du blé tendre d'hiver sur le dispositif avec rotations d'Auzeville. In Limites de potentialité de production du blé dans différents systèmes de culture et dans différentes zones méditerranéennes, Bari, Italy, 30 September-2 October 1981, pp. 215-225. Bologna, Italy: Istituto di Agronomia Generale e Coltivazioni Erbacee.

Rinaldi, M., Di Bari, V., De Giorgio, D., Maiorana, M., Rizzo, V. \& CARlone, G. (1992). Sunflower (Helianthus annuus L.) in two-year rotations with durum wheat, with or without catch soybean. In Proceedings of the $13^{\text {th }}$ International Sunflower Conference, Pisa, Italy, 7-11 September 1992, pp. 284-292. Toowoomba, Australia: International Sunflower Association.

Schneiter, A. A. \& Miller, J. F. (1981). Description of sunflower growth stages. Crop Science 21, 901-903.

Service Central d'Etudes Economiques et Statistiques (SCEES) (1996a). 25 ans de statistique agricole annuelle: rétrospective 1970-1994. Agreste, La Statistique Agricole, Données Chiffrées Agriculture 79, 18.

Service Central d'Etudes Economiques et Statistiques 
(SCEES) (1996b). Les pratiques culturales sur grandes cultures en 1994: tournesol. Agreste, Données Chiffrées Agriculture 85, 129-140.

Vannozzi, G. P., Salera, E. \& Baldini, M. (1990). Sunflower yield characteristics as affected by weed control, plant density, nitrogen level and sowing time. Helia 13, 73-86.

Vereecken, H., Jansen, E. J., HaCk-ten Broeke, M. J. D.,
Swerts, M., Engelke, R., Fabrewitz, S. \& Hansen, S. (1991). Comparison of simulation results of five nitrogen models using different data sets. In Soil and Groundwater Research Report, II. Nitrates in Soils (Ed. P. A. Finke), pp. 321-338. Luxembourg: Commission of the European Communities.

Wagner, D. \& Leterme, P. (1993). Optimiser la conduite du tournesol: mission possible. Oléoscope 14, 10-12. 